\title{
Collect mechanisms of oleic acid on fluorite and calcite minerals
}

\author{
Dong $\operatorname{LIN}^{1, \mathrm{a}}$, Guanghua NIE ${ }^{1,2, b_{*}}$, Guoju LUO ${ }^{1, \mathrm{c}}$, Zhipeng TANG ${ }^{1, \mathrm{~d}}$, \\ ${ }^{1}$ Mining College, Guizhou university,Guiyang,Guizhou550025, China . \\ ${ }^{2}$ Civil \& Environment Engineering College ,University of Science and Technology \\ Beijing,Biejing100083,China \\ ald12723262@163.com, ${ }^{b} 307885481 @ q q . c o m,+$ Corresponding authour, \\ '919302443@qq.com, ${ }^{\mathrm{d}} 547291872 @ q q . c o m$,
}

Key Words: Materials Studio; molecular mechanics; mechanism; calcite; fluorite

Abstract:The floatability influence of sodium oleate and oleic acid on fluorite, calcite were studied by flotation test. Zeta potential of fluorite and calcite was tested by Zeta Potential Analyzer. By Materials Studio software, the reagent action on mineral surface was simulated and the surface energy changes in this process were calculated. The research results shows that, the collect capability of sodium oleate on mineral is better than oleic acid, the floatability of fluorite is better than calcite, it is because that sodium oleate and oleic acid collect mineral by chemical adsorption of oleate ions on fluorite and calcite surface, the adsorption strength of oleate ions on fluorite is stronger than water and $\mathrm{OH}^{-}$, while on calcite it is just opposite. In the flotation system, the collecting ability of oleate ions on fluorite is strong, and less affected by the water molecules and $\mathrm{OH}^{-}$, however, the collecting ability of oleate ions on calcite is weaker than water molecules and $\mathrm{OH}^{-}$ions.

\section{Introduction}

Fluorite is one of the most important industrial minerals, with a wide range of applications, as new materials, nuclear industry, building materials, medicine, pesticides and other in emerging industries and traditional industries ${ }^{[1]}$. Chinese fluorite reserves have occupied the first place in the world, reach $2.6 \times 10^{8} \mathrm{t}$ and account for $2 / 3$ of the world's reserves ${ }^{[2]}$. However, $\mathrm{CaF}_{2}$ average grade is low and the vast majority of fluorite associated with other metal and non-metallic mineral ${ }^{[3 \sim 5]}$. Main gangue minerals in these ores are quartz, calcite and barite ${ }^{[6]}$. Calcite-type fluorite ore with high grade have rich reserves in China, flotation is the main and effective recovery method for processing these ores ${ }^{[7 \sim 8]}$. Flotation separation of fluorite minerals from the calcite ore is very difficult because their similarity floatability. Their similarity floatability is due to fluorite and calcite are salt minerals, the great similarity of physical and chemical properties such as their chemical composition, dissolving properties, crystal structure and reagent adsorption behavior and so on ${ }^{[9]}$. Action mechanism of reagents with mineral in flotation process is very complex. But by using various modern, study of collector action on mineral surface has made a lot of progress in recent years, especially the researches about the function of the collector and mineral surface ${ }^{[10]}$. Generally considered, collector adsorption on fluorite and calcite is affected by the $\mathrm{pH}$ of flotation systems ${ }^{[11]}$. Molecular mechanics method calculate faster than quantum chemistry methods, it could research the function of collector on mineral surface from the atomic level and well reveal the effect capability of pharmaceutical ingredients on mineral surface ${ }^{[12]}$.

Through flotation test in this paper, the floatability effects of sodium oleate and oleic acid on fluorite and calcite is studied. By Materials Studio software, the reagent action on mineral surface was simulated and the surface energy changes in this process were calculated, flotation mechanism of mineral is analysis from the angle of molecular and this analysis results is further used to analyze the flotation test results. 


\section{Experimental}

Materials. The fluorite sample from YanHe county in GuiZhou province. Calcite sample from PingBa county in GuiZhou province. Handle and choose a sample hammer broken, then hand pick and dry grind to the required size until dry select to obtain the required grade sample, afterwards placed in a glass container kept in reserve. Fluorite and calcite mineral are more than $98 \%$ purity by chemical analysis.

Test methods.Pure mineral flotation tests used XFG $\square$ hang slot flotation machine which speed is $2010 \mathrm{r} / \mathrm{min}$. Mineral pre-grounded to $-0.106 \mathrm{~mm}$, then weighed $4.0 \mathrm{~g}$ ore sample by used electronic balance, and tanked ore sample into $40 \mathrm{~mL}$ flotation cell, after that added deionized water adjusted the slurry $2 \mathrm{~min}$ and measured and recorded $\mathrm{pH}$ value after adjusted $\mathrm{pH}$ with $\mathrm{HCl}$ or $\mathrm{NaOH}$, in stirring $2 \mathrm{~min}$, afterwards added depressor stirring $2 \mathrm{~min}$ and added collector stirring $3 \mathrm{~min}$, flotation $5 \mathrm{~min}$. Filtered, dried, weighed, and calculate floating rate in the end.

Determination PZC by Zeta Potential Analyzer and ore samples required grinding to $-5 \mathrm{um}$, the measured was that weighed 50mg each time placed in small beaker then added appropriate amount of deionized water and adjusted the $\mathrm{pH}$ with $\mathrm{HCl}$ or $\mathrm{Na}_{2} \mathrm{CO}_{3}$ stirred for 2 minutes after that added depressor stirred for 10 minutes, measured zeta potential in the end which each repeated three times and averaged.

\section{Results and discussion}

Flotability influence of sodium oleate and oleic acid on fluorite and calcite.Fig1 and Fig 2 show flotability influence of sodium oleate and oleic acid on fluorite and calcite in different $\mathrm{pH}$ value. As can be seen, collecting capacity of sodium oleate on mineral greater than oleic acid. Fig 1 shows that fluorite was depressed when sodium oleate as collector at $\mathrm{pH}$ value less 4 , while fluorite flotation was very good on the condition of $\mathrm{pH}$ value more 4 . Recovery rate is not exceed 40 percent when oleic acid as the collector at $\mathrm{pH}$ value less 10 under laboratory medicine dosage. While with oleic acid as collector, fluorite recovery rate is increase rapidly when $\mathrm{pH}$ value more than 10 .

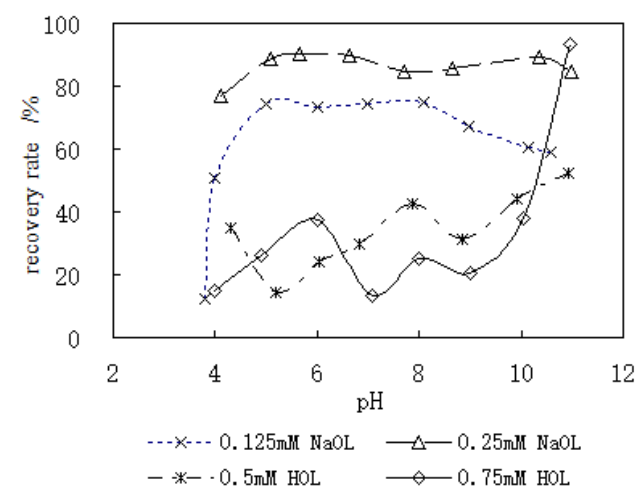

Fig.1 Flotation recovery of fluorite as a function of $\mathrm{pH}$ with various addition of $\mathrm{NaOL}$ and HOL 


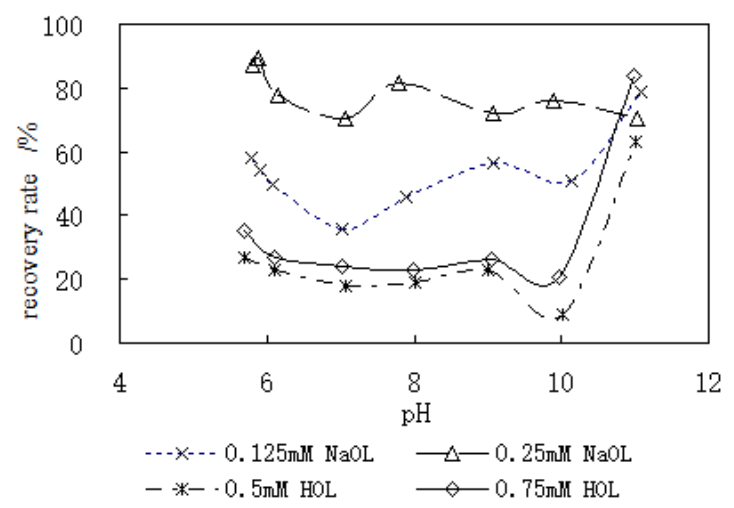

Fig.2 Flotation recovery of clcite as a function of $\mathrm{pH}$ with various addition of $\mathrm{NaOLand} \mathrm{HOL}$

Fig. 2 showed that collecting capacity of sodium oleate on mineral greater than oleic acid. Calcite recovery rate was lowest by sodium oleic as collector about $\mathrm{pH} 7$, while calcite can float well in other $\mathrm{pH}$ condition. Calcite flotability is best by oleic acid as collector above $\mathrm{pH} 10$ and the recovery rate is lowest at $\mathrm{pH} 10$.

Study on surface adsorption of oleate ions on fluorite and calcite. Table 1 showed that fluorite PZC was 10.0, through test result Fig. 1 can see fluorite can obtain good flotation when $\mathrm{pH}$ value more than 10.0. That shows fluorite flotation is due to chemisorptions of collectors on mineral surface. Calcite Pzc was 10.8. Figure 2 shows that calcite have good floatability when $\mathrm{pH}$ value in the range of 5-11 with $0.25 \mathrm{M}$ addition of sodium oleate. That indicated oleate ions collect calcite by chemisorptions manner. This also explained why mineral floatability increase at the condition of $\mathrm{pH}$ value more than 10 using oleic acid as collector in the flotation tests, it is because oleate ions resolved by oleic acid are adsorption on mineral surface under alkaline conditions.

Table 1 Solubility product constant and dynamic potential

\begin{tabular}{|c|c|c|c|}
\hline $\begin{array}{l}\text { minera } \\
1\end{array}$ & $\begin{array}{l}\mathrm{pKs} \\
\mathrm{o}\end{array}$ & ${ }_{1}$ IEP & $\mathrm{C}^{\mathrm{PZ}}$ \\
\hline $\begin{array}{l}\text { fluorit } \\
\mathrm{e}\end{array}$ & $3^{10 .}$ & 10 & 9.7 \\
\hline calcite & $7^{16 .}$ & $8^{10 .}$ & $0^{11 .}$ \\
\hline
\end{tabular}

In the flotation practice ${ }^{[13,14]}$, separated fluorite from calcite by oleic acid as collector under the condition of weak acid. it is unrealistic that collector adsorb mineral only by physical manner when fluorite and calcite surface is positively charged in these conditions. A large number of experimental studies ${ }^{[15,16]}$ have confirmed that flotation separated fluorite from calcite by oleate ions chemical adsorb in fluorite surface. Oleate ions and calcium ions of mineral surface in chemical reaction that formed calcium oleate. Above test results also explained the collector performance of oleate on fluorite and calcite was greater than oleic acid.

Study on effect of oleate ions on fluorite and calcite surface.In the Materials Studio software environment, Fig.3 and Fig.4 showed the crystal structure of the two minerals and interaction of oleic, water molecules and $\mathrm{OH}-$ on fluorite and calcite. Figure 5 showed interaction model of oleic acid with fluorite, calcite and fluorite with oleate ions and water molecules and $\mathrm{OH}^{-}$interaction energy shown in Table 2 and Table 3. 


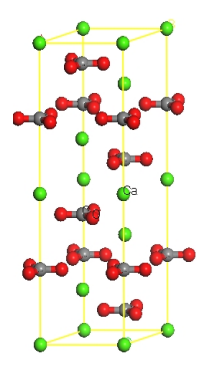

Crystal Structure

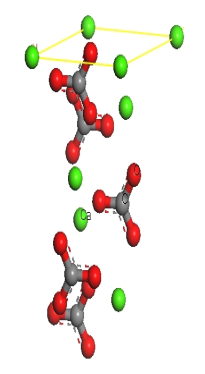

Cleavage Plane

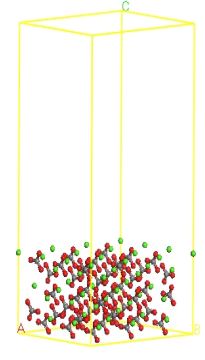

Supercell

Fig.3 Calcite Crystal Structure、Cleavage Plane、Super-cell Model

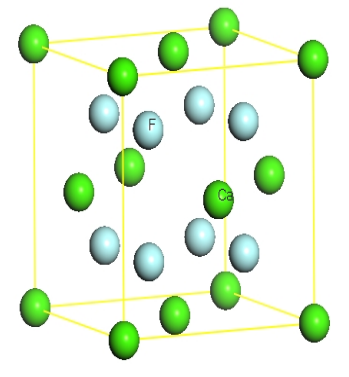

Crystal Structure

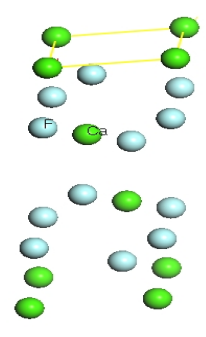

Cleavage Plane

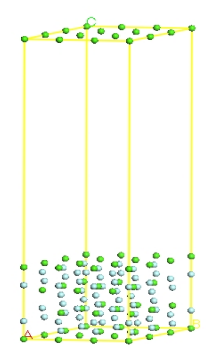

Supercell

Fig. 4 Dolomite Crystal Structure、Cleavage Plane、Super-cell Model
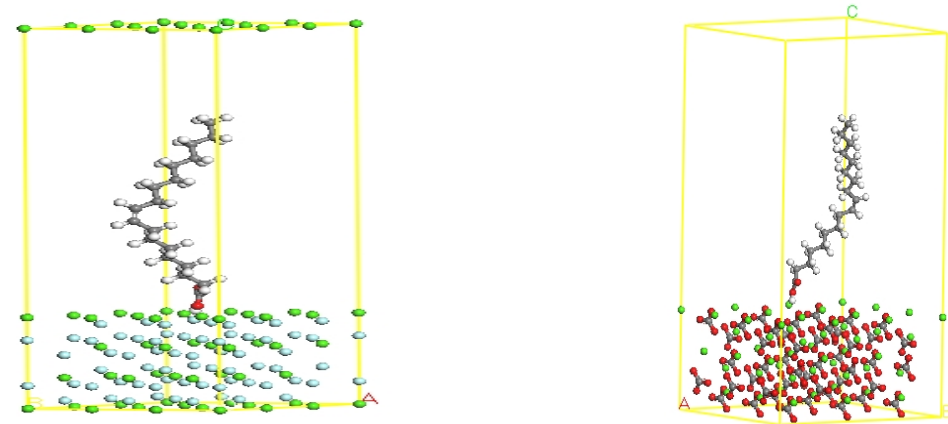

Interaction between oleic acid radical with fluorite

Interaction between oleic acid radical with calcite

Fig5. Interaction between oleic acid radical and fluorite , calcite 


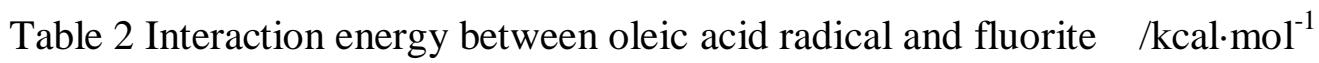

\begin{tabular}{|c|c|c|c|c|}
\hline \multirow{2}{*}{$\begin{array}{l}\text { Molecu } \\
\text { lar } \\
\text { Pharma } \\
\text { cy }\end{array}$} & \multicolumn{2}{|c|}{$\begin{array}{l}\text { Before system } \\
\text { energy }\end{array}$} & \multirow{2}{*}{$\begin{array}{c}\text { After system } \\
\text { energy } \\
\text { mineral+phar } \\
\text { macy }\end{array}$} & \multirow{2}{*}{$\begin{array}{c}\text { Interaction } \\
\text { energy } \\
\square \mathrm{G}_{\mathrm{water}}\end{array}$} \\
\hline & mineral & $\begin{array}{c}\text { Pharma } \\
\text { cy }\end{array}$ & & \\
\hline Oleic & $\begin{array}{c}68.01246 \\
9\end{array}$ & $\begin{array}{c}16.171 \\
657\end{array}$ & -70.090028 & -18.249216 \\
\hline water & $\begin{array}{c}- \\
68.01246 \\
9\end{array}$ & $\begin{array}{c}0.0000 \\
19\end{array}$ & -71.119349 & -3.106899 \\
\hline $\mathrm{OH}-$ & $\begin{array}{c}- \\
68.01246 \\
9\end{array}$ & $\begin{array}{c}0.0000 \\
09\end{array}$ & -70.429291 & -2.416831 \\
\hline
\end{tabular}

Table 3 Interaction energy between oleic acid radical and calcite $/ \mathrm{kcal} \cdot \mathrm{mol}^{-1}$

\begin{tabular}{|c|c|c|c|c|}
\hline \multirow{2}{*}{$\begin{array}{l}\text { Molecu } \\
\text { lar } \\
\text { Pharma } \\
\text { cy }\end{array}$} & \multicolumn{2}{|c|}{ Before system energy } & \multirow{2}{*}{$\begin{array}{c}\text { After system } \\
\text { energy } \\
\text { mineral+pharma } \\
\text { cy }\end{array}$} & \multirow{2}{*}{$\begin{array}{c}\text { Interaction } \\
\text { energy } \\
\square \mathrm{G}_{\text {water }}\end{array}$} \\
\hline & mineral & $\begin{array}{c}\text { Pharmac } \\
\mathrm{y}\end{array}$ & & \\
\hline Oleic & $\begin{array}{l}30387.5756 \\
38\end{array}$ & $\begin{array}{l}16.1716 \\
57\end{array}$ & -30915.325256 & -511.577961 \\
\hline water & $\begin{array}{l}30387.5756 \\
38\end{array}$ & $\begin{array}{l}0.00001 \\
9\end{array}$ & -30900.841251 & -513.265632 \\
\hline $\mathrm{OH}-$ & $\begin{array}{l}- \\
30387.5756 \\
38\end{array}$ & $\begin{array}{l}0.00000 \\
9\end{array}$ & -30907.829387 & -520.253758 \\
\hline
\end{tabular}

As can be seen from the data in Table 2 and Table 3 that oleic with fluorite and water with fluorite and $\mathrm{OH}^{-}$with fluorite interaction energies were $-18.249216 \mathrm{kcal} / \mathrm{mol},-3.106899 \mathrm{kcal} / \mathrm{mol}$, $2.416831 \mathrm{kcal} / \mathrm{mol}$, oleic with calcite and water with calcite and $\mathrm{OH}^{-}$with calcite interaction energies were $-511.577961 \mathrm{kcal} / \mathrm{mol},-513.265632 \mathrm{kcal} / \mathrm{mol},-520.253758 \mathrm{kcal} / \mathrm{mol}$, in which the interaction of agents with mineral surfaces more negative indicated that the interaction of agents with minerals more stronger ${ }^{[11]}$. Data described that adsorption capacity of oleic and water and $\mathrm{OH}^{-}$ on fluorite was greater than calcite. Table 4 showed that medicine on mineral surface energy variation data, $\square \mathrm{G}$ oleate ions - $\square \mathrm{G}$ water directed the capacity of oleic acid switch water which adsorbed on the surface of mineral, $\square$ G oleate ions - $\square$ G hydroxide directed the capacity of oleic acid switch hydroxide adsorbed on the surface of mineral . Data described the ability of oleic on fluorite can overcome the obstacle of water molecules and $\mathrm{OH}$ - ions adsorbed layer on the mineral surface. Data also showed that $\mathrm{OH}$ - ions to calcite have strongest inhibition ability and had small impact to fluorite flotation. This flotation test results were consistent and explained that oleate ions as fluorite collector have strong ability and influence by very small of $\mathrm{pH}$, but the collecting capacity was weak on calcite and subjected to large $\mathrm{pH}$ affected. 
Table 4 Energy change of reagent on mineral surface $/ \mathrm{kcal} \cdot \mathrm{mol}^{-1}$

\begin{tabular}{cccc}
\hline & \multicolumn{3}{c}{ Interaction energy difference } \\
\cline { 2 - 4 } mineral & $\square \mathrm{G}_{\text {oleic }}$ & $\square \mathrm{G}_{\text {oleic }}$ & $\square \mathrm{G}_{\text {hydroxide- }}$ \\
& $\square \mathrm{G}_{\text {water }}$ & $\square \mathrm{G}_{\text {hydroxide }}$ & $\square \mathrm{G}_{\text {water }}$ \\
\hline \multirow{2}{*}{ fluorite } & - & -15.832385 & 0.690068 \\
calcite & 15.142317 & 8.675797 & -6.988126 \\
\hline
\end{tabular}

\section{conclusions}

(1)Single mineral flotation test results show that, the collecting ability of sodium oleate is better than oleic acid and fluorite flotability is better than calcite, with sodium oleate collector, calcite recovery rate is low at about $\mathrm{pH} 7$.

(2)The result of zeta potential measurement confirmed that, it is precisely because the collector chemical adsorption on mineral fluorite can obtain good flotation recovery when $\mathrm{pH}$ above 10.0, oleate ions collecting of calcite is also accomplished by chemical adsorption, namely oleate and calcium cations in mineral surface chemically reacted form calcium oleate.

(3)The result of simulation and calculation by Materials Studio software show that, collect capability of sodium oleate on mineral is better than oleic acid, the flotability of fluorite better than calcite, it due to that sodium oleate and oleic acid collect mineral by chemical adsorption of oleate ions on fluorite and calcite surface.

\section{Acknowledgements}

The present work is supported by the Projects Supported of Guizhou province department (Grant No.20122174), The support are gratefully acknowledged. The authors are grateful to the reviewers for discerning comments on this paper.

\section{References}

[1] W L Wang, Z M Bai. Fluorite resources of china and present situation of industrial development. Journal of Metal Mine, Vol. (3)2014, p. 1-9.

[2] C M Xie, Z H Liu, H Chang, etc. Study on a fluorite ore in Guizhou flotation test. Journal of Metal Mine, Vol. (1)2009, p. 89-91.

[3] F T Yu, H M Gao, W T Shi, etc. Drug screening of mixed concentrate of a fluorite barite flotation separation. Journal of Metal Mine, Vol. (1)2013, p. 86-89.

[4] S X Liu, L L Shen, F S Niu. Study on the lower poverty difficult to choose fluorite ore in HeBei flotation technology. Journal of Non-metallic Mineral, Vol. (4)2010, p. 28 -29.

[5] H J Lv. Fluorite mineral resources sustainable exploitation and utilization of research in china. Journal of Mining Research and Development, Vol. (1)2005, p. 6-9.

[6] F Z Dong, J C Ren, X Z Liu, etc. Study on flotation separation of fluorite and barite. Journal of Non-Metallic Mineral, Vol.(24)2001, p.36- 37.

[7] W Z Yin, Z F Lv ,Y J Li . Study on PingQuan calcite-type fluorite ore 
experiment. Journal of Mining and Metallurgy,Vol.(1)2008,p.1-4.

[8] PUGH R, STENIUS P. Solution chemistry studies and flotation behaviour of apatite,calcite and fluorite minerals with sodium oleate collector. International Journal of Mineral Processing, Vol. (3)1985, p. 193-218.

[9] Z F Cao, H Zhong, Y Song, etc. The process mineralogy and flotation properties of Zhucang fluorite ore. International Journal of Mining Science and Technology. Vol. (3)2012, p. 439-445.

[10] Z Y Gao, W Sun, Y H Hu, etc. Anisotropic surface broken bond properties and wettability of calcite and fluorite crystals. Journal of Nonferrous Metals. Vol. (22)2012, p. 1203-1208.

[11] C L Yue. Study on fluorite, barite, calcite flotability. Journal of Chemical Mineral and Processing, Vol. (9): 2001, p.8-10.

[12] F L Wang, S G Luo, C Y Sun. Molecular mechanics of the unactivated smithsonite flotation behavor by xanthates. Journal of Nonferrous Metals (Concentration), Vol. (4)2008, p. 43-47.

[13] B Pradip. Molecular modeling and rational design of Flotation Reagents. Journal of Foreign Metallic Ore Dressing,Vol.(10) 2004, p. 28-34.

[14] C L Yue. Fluorite, barite, calcite flotability research. Journal of Chemical Mineral and Processing,Vol.(9)2001,p.8-10.

[15] T Zhou, W H Shi. Study on high calcium fluorite ore dressing experiment in JinTa county.Journal of Metal Mine, Vol.(3)2011,p.102-104.

[16] A. Kaer, X Y Yuan, S Lin. Adsorption mechanism in fluorite flotation collector. Journal of Foreign Metal Processing, Vol.(7)2003,p.20-23. 